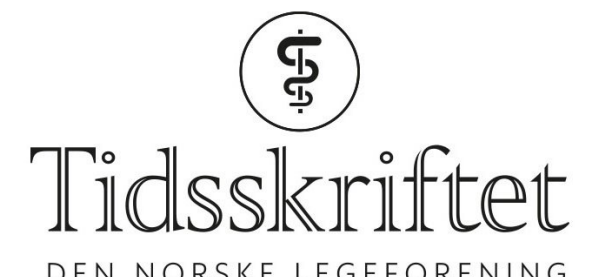

DEN NORSKE LEGEFORENING

\title{
Gjør livserfaring oss til bedre leger?
}

LEGELIVET

\section{KAVEH RASHIDI}

E-post: kavehrashidi@gmail.com

Kaveh Rashidi er fastlege ved Lovisenberg legesenter og forfatter.

Jeg var 23 år gammel da jeg fullførte legestudiet i Oslo. Ung og uerfaren gikk jeg legelivet i møte. Nå, åtte år senere, er jeg fortsatt ganske ung og uerfaren. I tillegg har jeg glemt mye teori, for hvem klarer vel å huske alt vi en gang lærte på studiet? Likevel tror jeg at jeg har blitt en bedre lege. Så klart er det mye på grunn av klinisk erfaring, men jeg tror det også har med noe helt annet å gjøre. Noe vi sjelden snakker om på studiet: livserfaring.

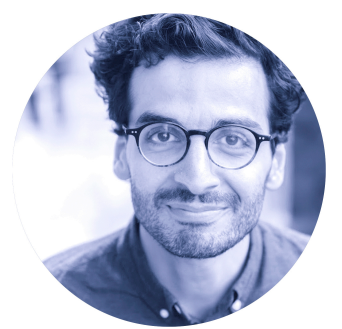

Foto: Jorunn Valle Nilsen

Gjennom de siste åtte årene har jeg opplevd en håndfull av livets opp- og nedturer. Det er ikke all verdens, men det har vært nok til å gi meg en bedre forståelse av menneskene jeg møter. Pasientene er jo aldri bare cellene og prøvesvarene vi har lært om, de er like mye sine erfaringer og oppfatninger. Enhver pasient har sin subjektive forståelse av verden, og selv om empati er et godt verktøy, kan det være godt å ha flere bein å stå på for å forstå pasienten.

La meg gi noen eksempler. Å være helsestasjonslege ble noe annet uken etter at jeg fikk en sønn. Engstelsen til foreldrene ble mer ekte, søvnløsheten tydeligere og lykken over å høre at alt er normalt, ble mer av en delt glede. Å være lege for pårørende av kreftsyke fikk ny mening etter at jeg mistet min søster og far til kreft. Jeg kunne bedre forstå ringvirkningene av kreft, og jeg tror simpelthen at jeg bryr meg mer om menneskene i den situasjonen nå. Selv de mest banale ting, som å skrive ut nesespray til pollenallergikere eller å forklare pasienten hvordan sykemeldinger fungerer, er enkle ting jeg mestrer bedre gjennom å ha opplevd det.

Det trenger ikke engang å være den samme opplevelsen, den generelle erfaringen av å være pasient eller pårørende er i seg selv nyttig - fra usikkerheten rundt de tidligere symptomene, gjennom utredninger og behandlinger til en konklusjon på den andre siden. Opplevelsene fra livet gjør oss til bedre leger.

Tror jeg. 
Kanskje tar jeg helt feil. Jeg måler tross alt ikke mitt eget arbeid og mine resultater på objektivt vis. Stort sett vurderer jeg hvor god lege jeg er ut ifra hvor tilfreds jeg oppfatter at pasienten er. Og en tilfreds pasient er ikke nødvendigvis en som har fătt den objektivt beste behandlingen. Faktisk vil jeg påstå at det ofte er enklere å gjøre pasienten tilfreds enn å drive godt legearbeid.

Så selv om pasientene virker fornøyde av å ha en lege som har personlig erfaring med noe de gjennomgår, kan det være at livserfaringen skaper en skjevhet i vurderingsevnen min? Henviser jeg for mange skjelende barn til øyelege fordi min egen unge trengte øyelapp? Stresser jeg kulene i kvinnebryst for mye fordi min søster hadde brystkreft? Går jeg rett på altfor sterk allergibehandling fordi jeg selv har hatt flere anafylaksier? Du skjønner poenget.

Vi vet at vi ikke skal tilegne enkelthistorier for mye vekt i våre avgjørelser som leger. Anekdoter og historier er ikke vitenskapelige bevis. Personlige erfaringer kan ha vært så sterke for meg at jeg tillegger dem en enorm betydning som igjen føres over til pasienten. Eller motsatt for den saks skyld, kanskje mestret jeg noe godt og bagatelliserer pasientens opplevelse av problemet.

Det finnes i det hele tatt en hel del farer i det å bruke egne livserfaringer, både når vi gjør det bevisst og ubevisst. Likevel tror jeg at det også finnes en enorm ressurs i våre erfaringer. Brukt på riktig måte kan de ha et potensial. Det er nyttig informasjon, enda et verktøy i arsenalet vårt, som kan komme pasientene til gode.

En enkelt variant av denne personlige erfaringen oppnår vi som legestudenter når vi tar blodprøver på hverandre eller dytter en pinne dypt i nesa på hverandre. Den mer komplekse varianten tror jeg vi bare kan få av å leve. For hva er vi uten erfaringene våre emosjonsløse datamaskiner som prosesserer objektive parametere og genererer diagnoser? Det vil ingen ha.

Nå har jeg mange år igjen foran meg som yrkesaktiv lege. Mange pasienter venter, og mange livserfaringer kommer til å forme meg. Så får jeg prøve å la disse to leve i harmoni med hverandre. En god spiral, der livet gjør meg til en bedre lege og legelivet gjør meg til et bedre menneske.

Publisert: 13. august 2020. Tidsskr Nor Legeforen. DOI: 10.4045/tidsskr.20.0503

(C) Tidsskrift for Den norske legeforening 2020. Lastet ned fra tidsskriftet.no 